\title{
Evaluation of in vitro Bioactivity of Melaleuca cajuputi Powell Essential Oil against Aedes aegypti (L.) and Aedes albopictus (Skuse) \\ (Penilaian Bioaktiviti in vitro Minyak Pati Melaleuca cajuputi Powell terhadap Aedes aegypti (L.) dan Aedes albopictus (Skuse)
}

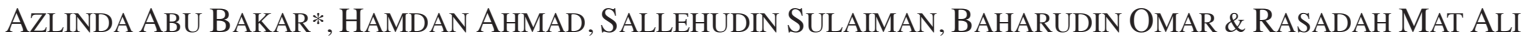

\begin{abstract}
The aim of this study was to evaluate the in vitro activity of Melaleuca cajuputi essential oil leaf extract against Aedes aegypti and Aedes albopictus. The essential oil of the M. cajuputi was obtained via steam hydro-distillation and analyzed by GC-MS for the chemical constituents. GC-MS analysis showed that the essential oil of M. cajuputi contained 13 compounds with two major chemical constituents, 2-propenoic acid (29.55\%) and caryophyllene (20.04\%). Adulticidal and larvicidal bioassay was evaluated following WHO guidelines. Larvicidal bioassays were conducted with the 10, 50, 80, 100, and $120 \mathrm{mg} / \mathrm{L}$ M. cajuputi essential oil against late $3^{\text {rd }}$ instar of Ae. aegypti and Ae. albopictus which give $L C_{50} 120.99 \mathrm{mg} / \mathrm{L}$ and $222.58 \mathrm{mg} / \mathrm{L}$, respectively. Adult mortality was observed after $24 \mathrm{~h}$ with the $L_{50}$ of $0.029 \mathrm{mg} / \mathrm{cm}^{2}$ for Ae. aegypti and $0.028 \mathrm{mg} / \mathrm{cm}^{2}$ for Ae. albopictus. In adulticidal bioassay, M. cajuputi essential oils showed effective results at 0.04 $\mathrm{mg} / \mathrm{cm}^{2}$ concentrations, with values for $K T_{50}$ of $77.71 \mathrm{~min}$ for Ae. aegypti and 69.49 min for Ae. albopictus. M. cajuputi essential oils exhibited moderate toxicity effects against the larva and adults of Aedes species and may be used as an alternative to chemical insecticide.
\end{abstract}

Keywords: Adulticidal; Aedes; essential oil; larvicidal; Melaleuca cajuputi

\section{ABSTRAK}

Tujuan kajian ini adalah untuk menilai aktiviti ekstrak daun minyak pati Melaleuca cajuputi secara in vitro terhadap larva Aedes aegypti dan Aedes albopictus. Minyak pati M. cajuputi diperoleh secara stim penyulingan-hidro dan dianalisis menggunakan GC-MS untuk menentukan komponen bahan kimia. Analisis GC-MS menunjukkan kandungan komponen kimia minyak pati M. cajuputi terdiri daripada 13 sebatian dengan dua unsur kimia utama iaitu asid 2-propenoik (29.55\%) dan kariofilena (20.04\%). Bioasai nyamuk dewasa dan larva dijalankan mengikut garis panduan WHO. Bioasai larva telah dijalankan dengan minyak pati M. cajuputi berkepekatan 10, 50, 80, 100, dan 120 mg/L terhadap instar 3 Ae. aegypti dan Ae. albopictus yang memberikan nilai $L_{50}$ masing-masing, ialah $120.99 \mathrm{mg} / \mathrm{L}$ dan $222.58 \mathrm{mg} / \mathrm{L}$. Kadar mortaliti nyamuk dewasa diperhatikan selepas 24 jam dan nilai $L C_{50}$ yang diperoleh bagi Ae. aegypti dan Ae. albopictus masingmasing, ialah $0.029 \mathrm{mg} / \mathrm{cm}^{2}$ dan $0.028 \mathrm{mg} / \mathrm{cm}^{2}$. Melalui ujian bioasai adultisid yang dijalankan, minyak pati M. cajuputi menunjukkan hasil yang efektif pada kepekatan $0.04 \mathrm{mg} / \mathrm{cm}^{2}$ dengan nilai $\mathrm{KT}_{50}$ ialah 77.71 min bagi Ae. aegypti dan 69.49 min bagi Ae. albopictus. Minyak pati M. cajuputi menunjukkan kesan ketoksikan sederhana terhadap larva dan dewasa spesies Aedes dan dapat digunakan sebagai insektisid alternatif terhadap insektisid bahan kimia.

Kata kunci: Adultisidal; Aedes; bioaktiviti; larvisidal; Melaleuca cajuputi; minyak pati

\section{INTRODUCTION}

The Ae.aegypti mosquito has emerged as one of the most dangerous vectors, as it is able to transmit Yellow fever, dengue, chikungunya, and Zika. Dengue is a serious arboviral disease of the Africa, America, and Asia. The spread of dengue fever and Yellow fever in many parts of the world can be directly attributed to the proliferation and adaptation of these mosquitoes to breeding and living close to human populations and settlings. The secondary vector, Ae.albopictus, which was originally confined to Asia and known as Asian Tiger mosquito, has also contributed to the spread of the dengue fever, chikungunya, and Yellow fever as well. Yellow fever, which has a 400-year history, occurs only in tropical areas of Africa and the Americas.
In Malaysia, dengue fever (DF) and dengue hemorrhagic fever (DHF) are the most common vector-borne diseases throughout the year across the nation, with occasional cases of chikungunya in some areas. However, both DF and DHF disease have a significant impact in shaping the socioeconomic development and the formation of a government and local authorities' policy (Packierisamy 2015). Dengue fever in Malaysia was first reported by Skae (1902). By the early 1970s, DHF had spread all of Malaysia and has since caused a significant health burden to the population. Until now, the most effective way to control vectorborne diseases has been relying on chemical insecticides. Chemical insecticides are shown to be effective in controlling the spread of the diseases during the outbreak 
by suppressing and eliminate the number of vector population (Lee et al. 2015). Organophosphates such as temephos, fenthion, and insect growth regulators such as diflubenzuron and methoprene are generally used for the control of mosquito larvae, whilst pyrethroids such as permethrin and deltamethrin, are used to control vector population of adult mosquitoes (Goindin et al. 2017). However, their repeated use has disrupted natural biological control systems and has led to outbreaks of insect species and the widespread development of resistance, leading to undesirable effects on non-target organisms and human health concerns (Yang et al. 2002). Therefore, there is an urgent need to develop an alternative pesticide which is environmentally safe, friendly and effective and thus has the potential to replace synthetic pesticides (Tapondjou et al. 2005).

In recent decades, research on the interactions between plants and insects has shown the potential use of plant metabolites for this purpose (Kamaraj et al. 2010). Indeed, in many cases plants have a history of use as home remedies to kill or repel insects (Kim et al. 2010). Hence, activities towards the exploring and screening of the potential of new plants and its chemical components in their insecticidal properties have increasingly been carried out among researchers worldwide (Abu Bakar et al. 2018). Chemicals derived from plants have been projected as weapons in future mosquito control programs, as they have been shown to function as general toxicants, growth and reproductive inhibitors, repellents and oviposition-deterrents (Sukumar et al. 1991). Currently, the screening of natural products has received the attention of researchers around the world (Kebede et al.2010), and many specific compounds have been isolated from plant extracts or essential oils and tested for their specific roles as insecticides (Maciel et al. 2010; Pavela 2009). The aim of this present study was to evaluate the effectiveness of $M$. cajuputi essential oil against Aedes spp.

\section{MATERIALS AND METHODS}

\section{MOSQUITO REARING}

The Ae.aegypti (L.) and Ae. albopictus used were from laboratory strain reared in the Vector Control Research Unit, School of Biological Sciences, Universiti Sains Malaysia. The mosquito colonies were maintained at 30$33^{\circ} \mathrm{C}$ and $60 \%-80 \%$ relative humidity. All larvae stages were provided with powdered food (a mixture of grounded dried cow liver, cat biscuit, vitamin B complex, powder milk, yeast). Larvae transformed into pupae stage will be transferred into the bowl containing water and placed in screened cages until they emerged into adults. The adults were provided with $10 \%$ sucrose solution on saturated cotton pads. For the bioassay testing, the larvae used were late $3^{\text {rd }}$ instar and/or early $4^{\text {th }}$ instar and the adult was $3-5$ days old.

\section{PLANT MATERIALS}

Plant leaves were collected from Mukim Telong, Kandis (5.9785463 North: 102.4265952 East) Bachok, Kelantan, Malaysia. The plant specimens were sent to Forest Research Institute of Malaysia (FRIM) in Kepong Selangor for species confirmation and kept at the Herbarium of Forest Biodiversity Division, with sample number PID 351016-23.

\section{EXTRACTION OF THE ESSENTIAL OILS}

The $M$. cajuputi essential oils were obtained from the extraction of leaves by performing a steam distillation process. The processing includes air-dried samples at room temperature for 5-7 days and later grounded to small particles. The grounded leaf particles were placed into the distillation flask $(500 \mathrm{~mL})$ and filled with distilled water $\left(60-70^{\circ} \mathrm{C}\right)$. The flask left to boil slowly at $100^{\circ} \mathrm{C}$ until distillation process completed. The distillation process completed when the essential oils had settled at the bottom layer of the water. The water layer was slowly drawn off and the remaining oil was transferred and kept in an airtight amber bottle in the refrigerator at $4^{\circ} \mathrm{C}$.

\section{PREPARATION OF THE SOLUTIONS}

The solution concentrations for the larvicidal and adulticidal bioassay were prepared according to WHO (2005). For the larvicidal bioassay, essential oil was diluted to $10 \%(\mathrm{v} / \mathrm{v})$, and five concentrations of $10,50,80,100,120$ $\mathrm{mg} / \mathrm{L}$ were prepared in $200 \mathrm{~mL}$ solutions using acetone as a solvent. $0.01 \%$ acetone and untreated tap water were used for positive and negative control, respectively. The solution for the adulticidal bioassay was prepared by dissolving essential oils in $70 \%$ ethanol with final concentrations of $0.026,0.03,0.034$, and $0.04 \mathrm{mg} / \mathrm{cm}^{2}$. Whatman No 1 . filter papers $(12 \mathrm{~cm} \times 15 \mathrm{~cm})$, were used for the paperimpregnated solutions. The paper was soaked in $2 \mathrm{~mL}$ of each concentration and allowed to dry at room temperature $\left(27-30^{\circ} \mathrm{C}\right)$. The prepared impregnated papers were then kept in aluminum foil and stored in a refrigerator at $4{ }^{\circ} \mathrm{C}$. Control used a paper consisting of $70 \%$ ethanol.

\section{BIOASSAY}

Larvicidal Bioassay Twenty larvae were placed in a plastic cup with $200 \mathrm{~mL}$ of aqueous suspension of tested essential oils at various concentrations. Five replicates per concentration were run simultaneously with a set of positive and negative controls. The number of dead larvae in each cup was counted after one and $24 \mathrm{~h}$ following exposure. The larvae are considered dead if they were immobile and do not respond to any mechanical touches after $24 \mathrm{~h}$. Larval mortality was recorded at $24 \mathrm{~h}$ post exposure. During observation, food was not supplied to the larvae.

Adulticidal Bioassay 25 adult females (3-5 days old) used in the bioassays were from batches of non-blood-fed 
mosquitoes. They were introduced into holding tubes then transferred to the exposure tube with a piece of treated filter paper. After $1 \mathrm{~h}$ in the exposure tube, mosquitoes were returned to the holding tube and provided a $10 \%$ sucrose. Malathion was used as positive control. Knockdown (1 h) and mortality (24 h) were recorded. According to WHO guidelines, a mosquito was scored dead or knockdown/ moribund when the legs or wings were impaired and the mosquito was unable to fly.

\section{ANALYSIS OF THE ESSENTIAL OILS}

Qualitative analysis of the chemical constituents was carried out using GCMS analysis under the following conditions: Alltech 15897 AT-1MS capillary column (30 $\mathrm{m} \times 0.25 \mathrm{~mm}$ ID $\times 0.25 \mu \mathrm{m}$, film thickness); held at $60^{\circ} \mathrm{C}$ for $1 \mathrm{~min}$, raised to $150^{\circ} \mathrm{C}$ at a rate of $6^{\circ} \mathrm{C} / \mathrm{min}$, raised to $240^{\circ} \mathrm{C}$ at a rate of $10^{\circ} \mathrm{C} / \mathrm{min}$, and held for $6 \mathrm{~min} ; 250^{\circ} \mathrm{C}$ injector temperature; carrier helium gas at a flow rate of 1.0 $\mathrm{mL} / \mathrm{min}$; 300:1 split ratio. Diluted oil $(0.1 \mu \mathrm{L}, 1: 10$, v/v, in dichloromethane) automatically injected into the system using a splitless mode. The oil components were identified by using GC-MS libraries (NIST107.LIB and WILEY229.LIB). The percentage of the identified component was computed via a total ion chromatogram (TIC).

\section{STATISTICAL ANALYSIS}

The data of mean larval mortality were subjected to probit analysis for calculating $\mathrm{LC}_{50}$ and $\mathrm{LC}_{90}$ as followed:

$$
\% \text { mortality }=\frac{\% \text { test mortality }-\% \text { control mortality }}{100-\text { control mortality }} \times 100
$$

Other statistics data were calculated at $95 \%$ confidence limits of upper confidence limit and lower confidence limit by using SPSS. Results with the P value less than 0.05 were statistically significant. The lethal concentrations $\left(\mathrm{LC}_{50}\right.$ and $\mathrm{LC}_{90}$ ) were calculated by probit analysis (Finney 1971).

\section{RESULTS AND DISCUSSION}

In this present study, we focused on the larvicidal and adulticidal properties of $M$. cajuputi (Powell) plant essential oils against the dengue vectors Ae. aegypti and Ae. albopictus. Various studies have been carried out by other researchers on the insecticidal properties of plant essential oils. M. cajuputi is a member of Myrtaceae family and an indigenous plant of Australia (Southwell \& Lowe 1999). In Malaysia, it is commonly found in swampy ground near the coasts (Corner 1997). The Aboriginal people of Australia use the leaves for numerous kinds of ill-treatment for centuries. In Asia, local people used its oil traditionally to relieve joint pain, stiff joints, and rheumatism, and as a mosquito repellent. In the Malay community it is known locally as 'gelam' or 'kayu putih', and the plant is highly adaptable in a wide range of conditions. GCMS analysis of the $M$. cajuputi essential oil compounds showed a total of 13 identified components representing $92.16 \%$ of total constituents (Table 1). The major constituents of the essential oil were 2-propenoic acid (29.55\%) and caryophyllene (20.04\%). All compounds detected under RT ranged from 11.206 min to $18.365 \mathrm{~min}$. Studies by Sakasegawa et al. (2003) on various types of Melaleuca spp. demonstrated that $M$. cajuputi collected from the residential area at Palembang (Indonesia) had four similar compounds to those of our $M$. cajuputi specimen, i.e. caryophyllene, $\alpha$-Humulene, $\delta$-Cadinene, and (-)-Spathulenol. However, their major constituents of the essential oil were 1,8-cineole (31.78\%), $\alpha$-Terpineol (11.88\%), and (-)-Globulol (10.38\%), and total percentages of detected chemical compounds were $82.03 \%$, with 25 identified chemical constituents. Similar studies by Kim et al. (2006) reported the differences in the chemical components of $M$. cajuputi essential oil leaf from six sampling locations. Minor components vary in terms of both structure and proportion but there were no differences in major components. Reasons for the differences and variety of the essential oil composition

TABLE 1. Chemical constituents of $M$. cajuputi essential oil

\begin{tabular}{clcc}
\hline Peak & Chemical components & Retention time $(\mathrm{RT})$ & Composition $(\%)^{*}$ \\
\hline 1 & Caryophyllene & 11.206 & 20.04 \\
2 & $\alpha$-Humulene & 11.663 & 2.92 \\
3 & $\alpha$-Gurjunene & 11.919 & 2.29 \\
4 & $\beta$-Selenene & 12.118 & 3.02 \\
5 & $\alpha$-Selinene & 12.228 & 3.60 \\
6 & d-Cadinene & 12.531 & 3.26 \\
7 & (-)-Spathulenol & 13.326 & 8.95 \\
8 & 2-Propenoic acid & 13.702 & 29.55 \\
9 & 1-Naphtalenol & 13.900 & 1.80 \\
10 & T-Muurolol & 14.076 & 5.33 \\
11 & $\alpha$-Cadinol & 14.262 & 7.54 \\
12 & Juniper camphor & 14.455 & 1.37 \\
13 & Ethanone & 18.365 & 2.49 \\
& Total & & 92.16 \\
\hline
\end{tabular}

*relative percentage of total essential oil compositions 
could be due to geographical location, components of soil minerals/quality, the maturity of the plant, seasonal diversity, genetic diversity, and the specific parts of the plants used for essential oil isolation (Anwar et al. 2009). The results of the larvicidal activity of the $M$. cajuputi essential oil are presented in Table 2. At the lowest concentration of $10 \mathrm{mg} / \mathrm{L}$, both Aedes spp. showed very minimal mortality of $3 \%$ and $1 \%$, respectively. Within 24 $\mathrm{h}$ post-exposure, mortality gradually increased to $55 \%$ and $23 \%$ at the highest concentration of $120 \mathrm{mg} / \mathrm{L}$. The M. cajuputi essential oil was more effective against $A e$. aegypti larvae populations compared to Ae. albopictus. There was a significant difference in mortality between Ae. aegypti and Ae. albopictus $(p<0.05 \mathrm{p}=0.04)$. A similar study by Jayakumar et al. (2016) reported that eucalyptus essential oil was the most effective among various plants tested against larvae and pupae of Culex quinquefasciatus with the $\mathrm{LC}_{50}$ values were 186.77 $\mathrm{mg} / \mathrm{L}$ and $206.08 \mathrm{mg} / \mathrm{L}$, respectively. In comparison, $M$. cajuputi essential oil in the present study gives lower $\mathrm{LC}_{50}$ of $120.99 \mathrm{mg} / \mathrm{L}$ against Ae. aegypti larvae. The potential of larvicidal properties in Myrtaceae plants essential oil was also recorded by Dias et al. (2015) against the Ae. aegypti larvae. The plants obtained from the Chapada das Mesas National Park, Brazil showed effectiveness with lethal concentrations $\left(\mathrm{LC}_{50}\right)$ ranging from 230 to $292 \mathrm{mg} / \mathrm{L}$. As known that botanical derivatives products are very unique, their results vary and exhibit a broad spectrum of bioactivities against different mosquito species at different concentrations. This has highlighted the need for further testing on the composition of tested essential oils.

Many plants essential oils have shown effectiveness when tested against mosquito larvae. However, most studies have failed to demonstrate adulticidal effects. Therefore, from the potential results obtained in the larvicidal efficacy, we tested the effects of the essential oils on the adults' mosquito. The results of adulticidal activity of essential oil are presented in terms of mean knockdown and mortality of Ae. aegypti and Ae. albopictus (Table 3). At the highest concentration of 0.04 $\mathrm{mg} / \mathrm{cm}^{2}$, both Aedes spp. gives $100 \%$ mean mortality within $24 \mathrm{~h}$ post exposure. Early exposure at the lowest concentration $0.026 \mathrm{mg} / \mathrm{cm}^{2}$, Ae. albopictus showed higher mean knockdown of $12.50 \pm 0.58$ compared to Ae. aegypti $6.50 \pm 0.58$. However, the mean knockdown of Ae. aegypti gradually increased during $1 \mathrm{~h}$ observation. The mean mortality was also gradually increased within 24 h post-exposure in both Aedes spp. tested populations. The statistical data of $\mathrm{LC}_{50} 95 \%$ confidence limits were also calculated. The results of the susceptibility test showed that $0.04 \mathrm{mg} / \mathrm{cm}^{2} M$. cajuputi essential oil exhibited the highest activity for Ae.aegypti $\left(\mathrm{LC}_{50}=0.029\right.$ $\left.\mathrm{mg} / \mathrm{cm}^{2}\right)$ and $A e$. albopictus $\left(\mathrm{LC}_{50}=0.028 \mathrm{mg} / \mathrm{cm}^{2}\right)$. It showed that mortality rates were at $100 \%$. This suggests that essential oil does not possess insecticidal properties at lower doses or at less than $0.04 \mathrm{mg} / \mathrm{cm}^{2}$. There was no significant difference in the mean mortality among two mosquito species $(p>0.05)$.

The different findings among two tested population species between Ae. aegypti and Ae. albopictus have comprehended the multifactorial contributions to mortality and survival of some mosquito species in certain conditions. According to a previous study (Brady et al. 2013), on the adult survival rate in Aedes spp., the Ae. albopictus has a higher survival rate than Ae. aegypti in the laboratory and field settings with ranges of important factors such as temperature and other environmental factors. In contrast, Ae. albopictus population in our study was more susceptible than Ae. aegypti. These small findings provide insight into the susceptibility/survival update status of both tested population species in this present study.

The biological properties of the plants are known to be dependent on their composition and products (essential oils, fixed oils, latex, resins, or extracts) (Dias et al.2015). Among the numerous plant-derived products, essential oils are considered to have the most variable

TABLE 2. Larvicidal bioassay of M. cajuputi essential oil against Aedes sp mosquito larvae

\begin{tabular}{|c|c|c|c|c|c|c|c|}
\hline Mosquitoes & $\begin{array}{l}\text { Dose } \\
(\mathrm{mg} / \mathrm{L})\end{array}$ & $\begin{array}{c}{ }^{1} \text { Mean } \\
\text { Mortality } \pm \text { SD }\end{array}$ & $\begin{array}{l}\text { Mortality } \\
(\%)\end{array}$ & $\begin{array}{l}\mathrm{LC}_{50}(\mathrm{mg} / \mathrm{L}) \\
(\mathrm{CI} 95 \%)\end{array}$ & $\begin{array}{c}\mathrm{LC}_{90}(\mathrm{mg} / \mathrm{L}) \\
\quad(\mathrm{CI} 95 \%)\end{array}$ & $\chi^{2}$ & $\mathrm{df}$ \\
\hline${ }^{2} A e$. aegypti & $\begin{array}{c}10 \\
50 \\
80 \\
100 \\
120 \\
* \text { Control }\end{array}$ & $\begin{array}{c}0.6 \pm 0.55 \\
3.0 \pm 0.71 \\
5.0 \pm 1.00 \\
7.8 \pm 0.84 \\
11.0 \pm 1.58 \\
0\end{array}$ & $\begin{array}{c}3 \\
15 \\
25 \\
39 \\
55 \\
0\end{array}$ & $\begin{array}{c}120.99 \\
(107.67-146.24)\end{array}$ & $\begin{array}{c}287.76 \\
(210.68-562.37)\end{array}$ & 2.266 & 2 \\
\hline $\begin{array}{l}{ }^{2} \text { Ae. } \\
\text { albopictus }\end{array}$ & $\begin{array}{c}10 \\
50 \\
80 \\
100 \\
120 \\
* \text { Control }\end{array}$ & $\begin{array}{c}0.2 \pm 0.45 \\
0.8 \pm 0.84 \\
2.8 \pm 1.3 \\
3.6 \pm 2.3 \\
4.6 \pm 1.14 \\
0\end{array}$ & $\begin{array}{c}1 \\
4 \\
14 \\
18 \\
23 \\
0\end{array}$ & $\begin{array}{c}222.58 \\
(162.05-607.11)\end{array}$ & $\begin{array}{c}659.84 \\
(332.84-6358.33)\end{array}$ & 0.506 & 2 \\
\hline
\end{tabular}


TABLE 3. Mean of knockdown and mortality of M. cajuputi essential oils against Aedes sp adult mosquitoes

\begin{tabular}{|c|c|c|c|c|}
\hline \multirow[b]{2}{*}{$\begin{array}{l}\text { Concentration } \\
\left(\mathrm{mg} / \mathrm{cm}^{2}\right)\end{array}$} & \multicolumn{2}{|c|}{ Ae. aegypti $(\mathrm{N}=100)$} & \multicolumn{2}{|c|}{ Ae. albopictus $(\mathrm{N}=100)$} \\
\hline & $\begin{array}{c}\text { Mean knockdown } \\
\pm \mathrm{SD}\end{array}$ & $\begin{array}{c}{ }^{\mathrm{a}} \text { Mean mortality } \\
\pm \mathrm{SD}\end{array}$ & $\begin{array}{c}\text { Mean } \\
\text { knockdown } \pm \text { SD }\end{array}$ & $\begin{array}{c}{ }^{\mathrm{b}} \text { Mean mortality } \\
\pm \mathrm{SD}\end{array}$ \\
\hline 0.026 & $6.50 \pm 0.58$ & $7.50 \pm 0.58$ & $12.50 \pm 0.58$ & $8.50 \pm 1.29$ \\
\hline 0.03 & $9.75 \pm 0.56$ & $12.50 \pm 2.89$ & $13.75 \pm 0.96$ & $16.25 \pm 0.50$ \\
\hline 0.034 & $18.00 \pm 0.82$ & $20.75 \pm 0.82$ & $15.25 \pm 2.63$ & $21.25 \pm 0.50$ \\
\hline 0.04 & $20.00 \pm 1.83$ & $25.00 \pm 0.00$ & $22.75 \pm 1.71$ & $25.00 \pm 0.00$ \\
\hline Malathion 5\% & $24.75 \pm 0.50$ & $25.00 \pm 0.00$ & $25.00 \pm 0.00$ & $25.00 \pm 0.00$ \\
\hline Ethanol $70 \%$ & 0 & 0 & 0 & 0 \\
\hline $\mathrm{LC}_{50}(\mathrm{CI} 95 \%)$ & \multicolumn{2}{|c|}{$\begin{array}{c}0.029 \\
(0.023-0.033)\end{array}$} & \multicolumn{2}{|c|}{$\begin{array}{c}0.028 \\
(0.027-0.029)\end{array}$} \\
\hline
\end{tabular}

$\mathrm{CI}=$ confidence intervals

${ }^{\mathrm{a}, \mathrm{b}}$ Not significantly difference at $p>0.05(\mathrm{p}=0.156)$

composition because of multifactorial factors such as soil, climate, altitude, age and part of the plant used (Barbosa et al. 2012; Feitosa et al. 2009). Many current types of research have recognized plant extracts and plant essential oil as important resources for botanical insecticides. Different part of plants contains a mixture of phytochemicals and secondary metabolites with distinctive biological activities (Ghosh et al. 2012). The diversity in the mosquitocidal activity of plant extracts is probably due to the differences in their active compounds, genetic characteristics of plant species and its harvested conditions (Sujatha et al. 1988).

The values of Knockdown Time (KT) in adulticidal bioassay are presented in Table 4 and a graph line (Figure $1)$. The values of $\mathrm{KT}_{50}$ were obtained from a probit analysis calculation using SPSS (v.24). Generally, the KT values of both Aedes spp. were lower with the increase of dose concentration. At the lowest concentration of 0.026 $\mathrm{mg} / \mathrm{cm}^{2}, \mathrm{KT}_{50}$ value for Ae. aegypti was $87.53 \mathrm{~min}$ (73.67$148.96 \mathrm{~min})$ and highest concentration of $0.04 \mathrm{mg} / \mathrm{cm}^{2}$ gives the $\mathrm{KT}_{50}$ of $77.71 \mathrm{~min}(64.05-168.20 \mathrm{~min})$. On the other hand, $\mathrm{KT}_{50}$ values of Ae. albopictus did not show the same pattern as Ae.aegypti. The highest value of $\mathrm{KT}_{50}$ was $92.59 \mathrm{~min}(78.88-124.43 \mathrm{~min})$ at a concentration of 0.034 $\mathrm{mg} / \mathrm{cm}^{2}$ instead of $0.026 \mathrm{mg} / \mathrm{cm}^{2}$. However, the lowest $\mathrm{KT}_{50}$ recorded was $69.61 \mathrm{~min}(61.15-101.75 \mathrm{~min})$ at the highest concentration of $0.04 \mathrm{mg} / \mathrm{cm}^{2}$. A positive control using 5\% malathion have the lowest $\mathrm{KT}_{50}$ for Ae.aegypti and Ae.albopictus of $36.09 \mathrm{~min}$ (33.71-38.45 $\mathrm{min}$ ) and $35.78 \mathrm{~min}$ (34.33-37.24 $\mathrm{min}$ ), respectively. The results of regression analysis showed that the $\mathrm{KT}_{50}$ values of $M$. cajuputi were negatively correlated with concentration $\left(\mathrm{mg} / \mathrm{cm}^{2}\right)$, and both Ae. aegypti and Ae. albopictus have a regression coefficient $\left(\mathrm{R}^{2}\right)$ of more than $0.5,0.6686$ and 0.5336 , respectively (Figure 1 ).

In this present study, results of M. cajuputi essential oil showed significant larvicidal activity. Previous studies on the effectiveness of $M$. cajuputi essential oils in aerosol form (Abu Bakar et al. 2012; Azlinda et al. 2009) have shown significant effects against adult mosquito dengue vectors. In general, essential oil act as contact insecticides, with a neurotoxic mode-of-action targeting gamma-aminobutyric acid (GABA) and octopamine synapses and acetylcholinesterase (Regnault-Roger et al. 2012). The mode of action of essential oils of mosquito larvae is not known, but the earlier studies stated that the plant chemicals initially affect the midgut epithelium, gastric caeca and Malpighian tubules in mosquito larvae

TABLE $4 . \mathrm{KT}_{50}$ values of $M$. cajuputi essential oils against Aedes sp adult mosquitoes

\begin{tabular}{lcc|cc}
\hline \multirow{2}{*}{$\begin{array}{l}\text { Concentration } \\
\left(\mathrm{mg} / \mathrm{cm}^{2}\right)\end{array}$} & \multicolumn{2}{c|}{ Ae.aegypti } & \multicolumn{2}{c}{ Ae.albopictus } \\
\cline { 2 - 5 } 0.026 & $\mathrm{KT}_{50}(\mathrm{CI} 95 \%)$ & Regression $\pm \mathrm{S} . \mathrm{E}$ & $\mathrm{KT}_{50}(\mathrm{CI} 95 \%)$ & Regression \pm S.E \\
& 87.53 & $0.05 \pm 0.02$ & 82.30 & $0.04 \pm 0.01$ \\
0.03 & $(73.67-148.96)$ & & $(71.26-118.55)$ & \\
& 82.07 & $0.05 \pm 0.01$ & 76.139 & $0.06 \pm 0.01$ \\
0.034 & $(71.36-117.0)$ & & $(68.93-91.46)$ & \\
& 79.56 & $0.04 \pm 0.01$ & 92.59 & $0.03 \pm 0.01$ \\
0.04 & $(70.10-97.09)$ & & $(78.88-124.43)$ & \\
& 77.71 & $0.04 \pm 0.01$ & 69.49 & $0.05 \pm 0.01$ \\
Malathion 5\% & $(64.05-168.20)$ & & $(61.15-101.75)$ & \\
& 36.09 & 35.79 & 35.78 & $5.13 \pm 0.30$ \\
\hline
\end{tabular}

$\mathrm{CI}=$ confidence intervals 


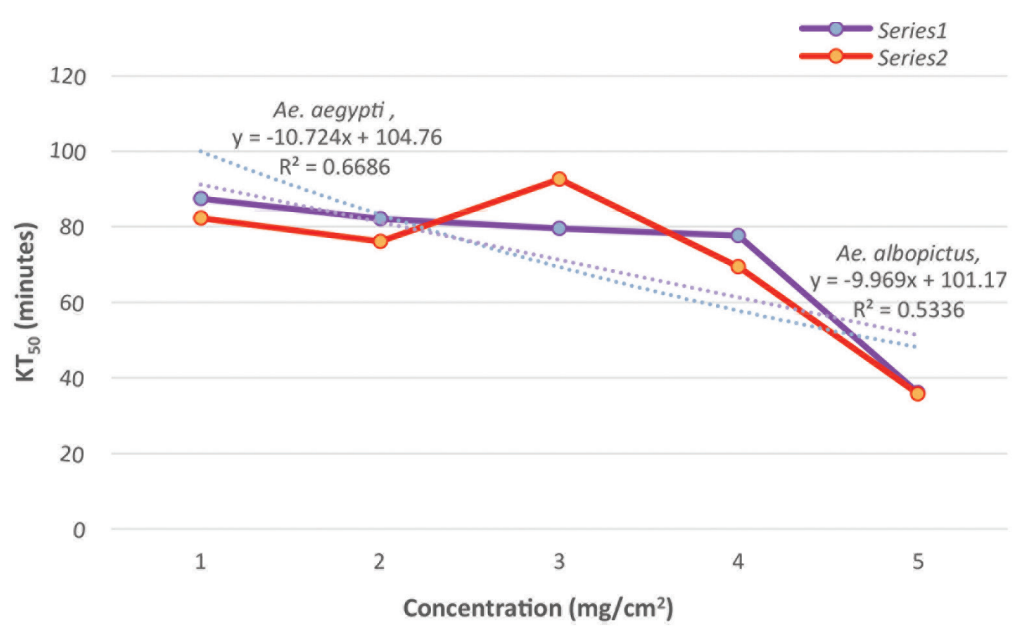

FIGURE 1. Relationship of $\mathrm{KT}_{50}$ of adulticidal activity of $M$. cajuputi essential oils against Ae.aegypti and Ae.albopictus mosquito adults

(David et al. 2000; Rey et al. 1999). According to a recent report by Govindaraju et al. (2016), other possible targets of essential oils are transient receptor type ion channels, acetylcholinesterase, and receptors tyramine, octopamine and GABA. Instead of synthetic insecticides, plant compounds could lead to the development of potent natural mosquitocidal products. Due to the volatile nature of plant essential oils, their insecticidal products are easily degraded, which leads to a lower level of risk to the environment than synthetic insecticides. Masetti (2016) has suggested in his report that essential oil based products should be effective under a wide range of field conditions (organic matter in the water, salinity, temperature, $\mathrm{pH}$ ) and different levels of susceptibility among mosquito species should also be considered. The variations in mortality and lethal concentration could be due to insecticidal ingredients of plants, time of collection and season (Sosan et al. 2001).

\section{CONCLUSION}

The findings of this study have demonstrated a moderate effect on larval and adult mortality induced by M. cajuputi essential oil against Ae. aegypti and Ae. albopictus. In brief, the essential oil from $M$. cajuputi leaves may be explored as a potential bio-insecticide and could be used as an alternative to chemical and synthetic insecticides. However, further studies are needed to assess the effects of individual compounds in both laboratory and semifield conditions on larval and adult mortality and the mechanisms involved.

\section{ACKNOWLEDGEMENTS}

We wish to thank the School of Medical Sciences, Health Campus, Universiti Sains Malaysia, Kubang Kerian Kelantan and Vector Control Research Unit, School of Biological Sciences, Universiti Sains Malaysia, Penang for supporting this study. The study was supported by the Universiti Sains Malaysia Short Term Grant, 304/ PPSP/61313037.

\section{REFERENCES}

Abu Bakar, A., Sulaiman, S., Omar, B. \& Ali, R.M. 2018. Screening of five plant extracts for larvicidal efficacy against larvae of Aedes aegypti (L.) and Aedes albopictus (Skuse). ASM Science Journal 11(2): 103-116.

Abu Bakar, A., Sulaiman, S., Omar, B. \& Mat Ali, R. 2012. Evaluation of Melaleuca cajuputi (Family: Myrtaceae) essential oil in aerosol spray cans against dengue vectors in low cost housing flats. Journal of Arthropod-Borne Disease 6(1): 28-35.

Anwar, F., Hussain, A.I., Sherazi, S.T.H. \& Bhanger, M.I. 2009. Changes in composition and antioxidant and antimicrobial activities of essential oil of fennel (Foeniculum vulgare Mill) fruit at different stages of maturity. Journal of Herbs, Spices and Medicinals Plants 15: 187-202.

Azlinda, A.B., Sallehudin, S., Baharudin, O. \& Rasadah, A. 2009. Evaluation of Melaleuca cajuputi Powell (Family: Myrtaceae) extract in aerosol can against dengue vectors in the laboratory. The Journal of Tropical Medicine and Parasitology 32: 58-64.

Barbosa, P.C.S., Medeiros, R.S., Sampaio, P.T.B., Vieira, B.G., Wiedemann, L.S.M. \& Veiga, V.F. 2012. Influence of abiotic factors on the chemical composition of copaiba oil (Copaifera multijuga hayne): Soil composition, seasonality and diameter at breast height. Journal of the Brazilian Chemical Society 23(10): 1823-1833.

Brady, O.J., Johansson, M.A., Guerra, C.A., Bhatt, S., Golding, N., Pigott, D.M., Delatte, H., Grech, M.G., Leisnham, P.T., Maciel de-Freitas, R., Styer, L.M., Smith, D.L., Scott, T.W., Gething, P.W. \& Hay, S.I. 2013. Modelling adult Aedes aegypti and Aedes albopictus survival at different temperatures in laboratory and field settings. Parasites \& Vectors 6: 351

Corner, E.J.H. 1997. Wayside Trees of Malaya. $4^{\text {th }}$ edition. Kuala Lumpur: Malayan Nature Society.

David, J.P., Rey, D., Pautou, M.P. \& Meyran, J.C. 2000. Differential toxicity of leaf litter to dipteran larvae of mosquito developmental sites. Journal of Invertebrate Pathology 75: 9-18. 
Dias, N.C., Alves, L.P.S., da Franca Rodrigues, K.A., Brito, M.C.A., dos Santos Rosa, C., do Amaral, F.M.M., dos Santos Monteiro, O., de Aguiar Andrade, E.H., Soares Maia, J.G. $\&$ Coutinho Moraes, D.F. 2015. Chemical composition and larvicidal activity of essential oils extracted from Brazilian legal Amazon plants against Aedes aegypti L. (Diptera: Culicidae).Evidence-Based Complementary and Alternative Medicine 2015: 490765.

Feitosa, E.M.A., Arriaga, A.M.C., Santiago, G.M.P., de Lemos, T.L.G., de Oliveira, M.C.F., eVasconcelos, N.J., Lima, J.Q., Malcher, G.T., do Nascimento, R.F. \& Braz Filho, R. 2009. Chemical composition and larvicidal activity of Rollinia leptopetala (Annonaceae). Journal of the Brazilian Chemical Society 20(2): 375-378.

Finney, D.J. 1971. Probit Analysis. $3^{\text {rd }}$ edition. Cambridge: Cambridge University Press.

Ghosh, A., Chowdhury, N. \& Chandra, G. 2012. Plant extracts as potential mosquito larvicides. Indian Journal of Medical Research 135(5): 581-598.

Goindin, D., Delannay, C., Gelasse, A., Ramdini, C., Gaude, T., Faucon, F., David, J.P., Gustave, J., Vega-Rua, A. \& Fouque, F. 2017. Levels of insecticide resistance to deltamethrin, malathion, and temephos, and associated mechanisms in Aedes aegypti mosquitoes from the Guadeloupe and Saint Martin islands (French West Indies). Infectious Diseases of Poverty 6(1): 38.

Govindaraju, S., Karthik, C. \& Indra Arulselvi,P. 2016. Evaluation of chemical composition and larvicidal activity of Coleus aromaticus essential oil, its major compound carvacrol against Aedes aegypti, Culex quinquefasciatus and Anopheles stephensi (Diptera: Culicidae). International Journal of Mosquito Research 3(3): 6-11.

Jayakumar, M., Arivoli, S., Raveen, R. \& Tennyson, S. 2016. Larvicidal and pupicidal efficacy of plant oils against Culex quinquefasciatus Say 1823 (Diptera: Culicidae). Journal of Entomology and Zoology Studies 4(5): 449-456.

Kamaraj, C., Abdul Rahman, A., Bagavan, A., Abduz Zahir, A., Elango, G., Kandan, P., Rajakumar, G., Marimuthu, S. \& Santhoshkumar, T. 2010. Larvicidal efficacy of medicinal plant extracts against Anopheles stephensi and Culex quinquefasciatus (Diptera: Culicidae). Tropical Biomedicine 27(2): 211-220.

Kebede, Y., Gebre-Michael, T. \& Balkew, M. 2010. Laboratory and field evaluation of neem (Azadirachta indica A. Juss) and Chinaberry (Melia azedarach L.) oils as repellents against Phlebotomus orientalis and P. bergeroti (Diptera: Psychodidae) in Ethiopia. Acta Tropica 113(2): 145-150.

Kim, J.H., Liu, K.H., Yoon, Y., Sornnuwat, Y., Kitirattrakarn, T. \& Anantachoke, C. 2006. Essential leaf oils from Melaleuca cajuputi. Traditional medicine and nutraceuticals ISHS. III WOCMAP congress on medicinal and aromatic plants. Acta Horticulturae 6: 680.

Kim, S.I., Yoon, J.S., Jung, J.W., Hong, K.B., Ahn, Y.J. \& Kwon, H.W. 2010. Toxicity and repellency of origanum essential oil and its components against Tribolium castaneum (Coleoptera: Tenebrionidae) adults. Journal of Asia-Pacific Entomology 13(4): 369-373.

Lee, H.L., Rohani, A., Khadri, M.S., Nazni, W.A., Rozilawati,H., Nurulhusna, A.H., Nor Afizah, A.H., Roziah, A., Rosilawati, R. \& Teh, C.H. 2015. Dengue vector control in MalaysiaChallenges and recent advances. The International Medical Journal Malaysia 14(1): 11-16.
Maciel, M.V., Morais, S.M., Bevilaqua, C.M.L., Silva, R.A., Barros, R.S., Sousam, R.N., Sousa, L.C., Brito, E.S. \& Souza-Net, M.A. 2010. Chemical composition of Eucalyptus spp. essential oils and their insecticidal effects on Lutzomyia longipalpis. Veterinary Parasitology 167: 1-7.

Masetti, A. 2016. The potential use of essential oils against mosquito larvae. Bulletin of Insectology 69(2): 307-310.

Packierisamy, P.R., Ng, C.W., Dahlui, M., Inbaraj, J., Balan, V.K., Halasa, Y.A. \& Shepard, D.S. 2015. Cost of dengue vector control activities in Malaysia. The American Journal of Tropical Medicine and Hygiene 93(5): 1020-1027.

Pavela, R. 2009. Larvicidal properties of essential oils against Culex quinquefasciatus Say (Diptera: Culicidae). Industrial Crops and Products 30: 311-315.

Regnault-Roger, C., Vincent, C. \& Arnason, J.T. 2012. Essential oils in insect control: Low-risk products in a high-stakes world. Supplemental Material Annual Review of Entomology 57: 405-424.

Rey, D., Pautou, M.P. \& Meyran, J.C. 1999. Histopathological effects of tannic acid on the midgut epithelium of some aquatic dipteral larvae. Journal of Invertebrate Pathology 73: 173-181.

Sakasegawa, M., Hori, K. \& Yatagai, M. 2003. Composition and antitermite activities of essential oils from Melaleuca species. Journal of Wood Science 49: 181-187.

Skae, F.M.T. 1902. Dengue fever in Penang. British Medical Journal 2(2185): 1581-1582.

Sosan, M.B., Adewoyin, F.B. \& Adewunmi, C.O. 2001. Larvicidal properties of three indigenous plant oils on the mosquito of Aedes aegypti. Nigerian Journal of Natural Products and Medicine 5: 30-33.

Southwell, I. \& Lowe, R. 1999. Tea tree, the genus Melaleuca. In Medicinal and Aromatic Plant Industrial Profile. Volume 9. Reading: Harwood Academic Publishers. pp. 11-28.

Sujatha, C.H., Vasuki, V., Mariappan, T., Kalyanasundaram, M. \& Das, P.K. 1988. Evaluation of plant extracts for biological activity against mosquitoes. International Pest Control 30: 122-124.

Sukumar, K., Perich, M.J. \& Boobar, L.R. 1991. Botanical derivatives in mosquito control. Journal of American Mosquito Control Association 72: 210-237.

Tapondjou, A.L., Adler, C., Fontem, D.A., Bouda, H. \& Reichmuth, C. 2005. Bioactivities of cymol and essential oils of Cupressus sempervirens and Eucalyptus saligna against Sitophilus zeamais Motschulsky and Tribolium confusum du Val. Journal of Stored Products Research 4: 191-102.

WHO. 2005. Guidelines for Laboratory and Field Testing of Mosquito Larvicides. WHO/CDS/WHOPES/ GCDPP/2005.13.

Yang, Y.C., Lee, S.G., Lee, H.K., Kim, M.K., Lee, S.H. \& Lee, H.S. 2002. A piperidine amide extracted from Piper longum L. fruitshows activity against Aedes aegypti mosquito larvae. Journal of Agricultural and Food Chemistry 50(13): 37653767.

Azlinda Abu Bakar*

Department of Medical Microbiology \& Parasitology

School of Medical Sciences

Universiti Sains Malaysia

16150 Kubang Kerian, Kelantan Darul Naim

Malaysia 
Hamdan Ahmad

Vector Control Research Unit

School of Biological Sciences

11800 USM, Minden Pulau Pinang

Malaysia
*Corresponding author; email: azlindaab@usm.my

Received: 4 February 2019

Accepted: 13 June 2019 